\title{
A Study on the Current Theories of the Philosophy and Principles of Self-Defense
}

\section{Parviz Khozouie ${ }^{1}$, Khalil Afandak ${ }^{2}$ and Mina Mehrvand ${ }^{3}$}

\author{
1 Department of Law, Ardabil Branch, Islamic Azad University, Ardabil, Iran. Email: p.khozoye695@gmail.com \\ 2 Department of Law, Ahar Branch, Islamic Azad University, Ahar, Iran. \\ 3 Department of Law, Ilkhchi Branch, Islamic Azad University, Ilkhchi, Iran
}

\begin{abstract}
The self-defense entity is a legal phenomenon which is included in most countries' constitution in order to protect the people right when exposed to a current or potential danger or offense. The philosophy of acceptance of the self-defense is based on the theories of natural rights, social contract, the two-right conflict, and spiritual obligation. The self-defense has been justified based on several principles such as less harmful results, the possibility of blaming the offender, offending and attacking the defender's right to live, the offender's responsibility, the defender's right for removal and denial of threat. The legal systems each complying with the social and cultural conditions and status, beliefs, the traditions, and etc. try to develop the conditions of realization of self-defense in their constitution, however there are common areas and differences between the legal systems and determination of them plays an important role in justifying this entity. This criminal entity is among the justifiable factors of crime that in case of inclusion of its conditions, the defender will bear no criminal and civil responsibility.
\end{abstract}

Keywords: Self-defense. The justified factors of crime. The proportionality of defense. The necessity of defense. Legal system.

\section{INTRODUCTION}

Defense is an innate sense of humanity. Human being has never surrendered against any unfair and illegitimate act and considers defense against such acts, as his natural right since he innately reciprocates the danger. The need to protect human dignity, based on an untouchable and undue principle, demands every man to be immune to invasion and offenses by others. Therefore, based on this fact, this right can be granted to anybody whose life and soul, freedom, honor, or land is seriously threatened, to defend his rights and take any actions to repel the aggression. Also, the legally defending of the fixed legal institutions and facilities in different systems is among the manifests of their common spirit whose originality has not been ignored due to change in the time and space and since it is based on the human nature, it has been considered as a natural rule. The basis of self-defense in the law is based on legal theories, including the necessity of defense as the implementation of a right or an assignment and the thesis of defense based on a mental force (spiritual).

Generally, in the social life, the people do not have the right to defend themselves directly except in some exceptional cases and circumstances, but this assignment is on the government that should defend the rights of people and support them. Regarding the extensiveness of humanitarian and human communities and despite the fact 
that the government cannot defend the people everywhere and in any circumstances, human naturally reacts against the threats. Therefore, the countries' legislators and legal systems, consider the self-defense for the individuals under specific terms and conditions and people, by the use of this right, can enforce this legal phenomenon against imminent dangers to their life, property, and honor.

The current study, which is extracted from a post-graduate thesis, besides providing several definition of self-defense, aimed at evaluation of the current theories on philosophy and principles of self-defense. It is hoped that this research could, though tiny, be a step towards understanding the causes of self-defense and its basic grounding in the science of law, and as a result, by accepting its application, the human rights be more supported by the communities.

\section{THE CONCEPT OF SELF-DEFENSE}

There are several views and theories on self-defense, especially in the nature of selfdefense and its philosophy and principles, among the legal systems of the countries. Self-defense has been studied in different aspects and several definitions have been proposed by the scholars and jurists, some of which we are going to discuss.

The definition of self-defense in the legal terminology book is as follows: "the offended person in case of lack of time to appeal to the government forces has the right to defend his honor, soul, and property by his own power, in order to remove aggression. This defense is called "self-defense" (JAFARI LANGRODI, 2005).

The self-defense or legal defense is the ability to remove the potential aggression

Estação Científica (UNIFAP)

ISSN 2179-1902 or unfair doing that endangered one's soul, land, honor, property, or freedom (ARDABILI , 2008).

Also, the self-defense has been defined as follows: "it is the removal of illegible offense to the soul and body, honor and land, or freedom of someone, in the framework" (VALIDI, 1995, p. 161).

Self-defense is known as the any person's right to defend his life, property, and honor. Regarding these definitions, it can be said that self-defense can be done when there is potential threat and there are no other ways to avoid the offender. Also, the defense must be in accordance with the offender's offense, i.e. to the extent that obviates the danger and also the defending should not be with the aim of revenge or offender's harassment. Therefore, the act of self-defense in the countries law is restricted to some conditions such as the necessity and proportionality of the defender's act with the offender's offense. Also there is another definition of the selfdefense as follows: "self-defense is application of any power to eliminate and obviate the danger and aggression of the offender, permissible and allowed by the law" (MIRMOHHAMMAD SADEGHI, 2012, p. 309).

The self-defense, as one of the factors of justification of the crime, is defined as follows: "the act of someone who commits a crime for self-defense or defending the others, which is known as a crime in other situations, is acceptable and therefore, not only the person who commits the crime, but also the accomplice who helped him, shall not be blamed and prosecuted" ( BARKIR AND PADFILD, 2011, 296).

In general, it can be said that the selfdefense, as an instrument of 'Abaheh' 
(permitting) (the justification for the crime or the causes that obviate the responsibility), is accepted by all the countries and legal systems worldwide. However, regarding the difference in its philosophy and principles in the legal systems, it has inevitably multiple and different definitions.

\section{THE PHILOSOPHY OF SELF-DEFENSE}

The self-defense, in different legal systems and different eras, has been named 'legal defense', 'legitimate defense', 'selfdefense', and etc., and to date, they are still being used. Despite the adoption of this principle in all legal systems, in relation to the legitimacy, there are disagreements among the theorists and scholars of the science. In relation to the legitimacy, there are disagreements among theorists. Some scholars consider the self-defense based on the defender, the status while defending, and conditions, while the others view it from the perspective of emphasis on the act of the offender. Some other scholars also justify the defender act with the intervention of the society as the third factor.

\subsection{Natural law theory}

Some scholars of law have referred to the concept of natural law for justifying the self-defense. They argument that the necessity for human survival is defending himself, since life is a natural right and heavenly gift. Therefore, defending it, is also necessary. This theory was first introduced by Cicerone, the Roman philosopher, and then others also supported it. Cicerone believes that self-defense is a natural rule and not a civil one. The nature has delegated the selfdefense to human, rather than being grant- ed as a result of regulations. According to this theory, when a right is among the natural rights, defending this right is also a natural human right and when a right is not among the natural rights, defending this right is also not a natural human right. This theory has only accepted self-defense for defending the life and has not accepted it for the property and other subjects, which is a place of criticism since the subject of self-defense is not just confined to the life, rather the property, honor, and lands are also among the subjects included in the self-defense and defending these cases is also necessary in the countries constitutions.

\subsection{Social contract theory}

This theory was developed by JeanJacques Rousseau, the famous French philosopher. He is otherwise justified selfdefense. He, by resorting to the social contract, believes that man is a social being and should live in society with his fellows and he is required to abide by the rights and systems necessary for the preservation and conservation of community. This is an obligation spontaneously created as soon as the person enters the society and accepts the fellowship. As a result, it can be said that as soon as the social contract is violated, the person whose rights and interests are affected or compromised, holds the right or is required to defend his rights and interests and establish the justice by appropriate means (ROSO, 2013).

It seems this theory will also be objected. This theory is used in such a way that selfdefense is considered to be a task or assignments rather than being recognized as a right for the defender. In addition, it has 
regarded the philosophy of self-defense as defending the society rights and protecting the social interests, however, the selfdefense, before defending the rights of people and society, is more of a protection of the individual's rights.

\subsection{The Two-Right Conflict Theory}

This theory, in legitimizing the selfdefense, puts that whenever two rights are in a such a conflict that in order for one of them to survive, the other one must be eliminated, logically and reasonably, the right with the higher value must be maintained. Therefore, the right of someone who is illegally and illegibly offended is prioritized over the right of the offender or attacker, so he must be supported by the law. In this regard, Hegel, the famous German philosopher, in justifying the selfdefense and elaborating its legal basis, asserts that: "offense is the denial of right and defense is the denial of the offense and consequently, defense is the implementation of the right" (ARDABILI, 2011).

The objection of this theory is that basically, there are no two rights, so there are no conflicts existing between them. The attack of the offender is not a right but it is an illegal and eligible act. Since all human beings have the right of freedom and can live freely and nobody can deny this right. In the normal situation, nobody is allowed to offend the others. If he attacked or offended, his act is illegible and must be reacted to and be obviated.

\subsection{The spiritual obligation theory}

The pros of this theory believe that the person who is threatened or attacked, due to excitement and distortion of will, cannot control his acts and he is obliged to commit a crime (ARDABILI, 2011).

Regarding this theory, the crime's nature is not changed while defending, but since the person has no will, the act is not attributed to him, since he had no will or option.

In this regard, exemption of punishment is a personal cause rather than a generic one. There are also objections to this theory. It may be justifiable while defending one's life, but it is not welcomed when defending the life and property of someone else since in such situations, the defender enjoys full authority and free will.

There is another justification that is the attack of the offender or attacker indeed disclaims the freedom of the defender. Therefore, if the defender has to commit a crime, he will not be blamed. The latter objection also can be applied to this justification (BAHERI, 2004). It should be considered that in the spiritual obligation theory, the self-defense is amongst the most important ablative causes of criminal responsibility; however in most countries and criminal law systems, the self-defense is amongst the most important factors in confronting the crimes.

\subsection{Islamic Law Theory}

The self-defense is recognized as a right in the Islamic law. Even the Shiite scholars consider the self-defense as a religious duty and obligation in some situations and conditions. According to the Islamic law, defending the life, property, and privacy is as much as the ability of person and the blood of offender who is injured or killed during the defense, is wasted (SHAMBAYATY, 
2008).

The Almighty God, in the Quran, in the verse 193 of Surah 'Baqara', asserts: "if someone eligibly offended and attacked you, respond to him the same way" (QOUNG, 2007).

The first scholar who considered this type of defense is Sheikh Toosi. He has written in the book "Al-Nahayah", which is one of the main resources of jurisprudence, "the thief is also an offender. When the thief attacks the person, he is allowed to confront him and push him away, and if this defense leads to the death of the thief, no reprimand and blood money will be upon the defender and his blood is wasted"(BORJE, 2005). Also, in another book of his, named "Al-Mabsut fi Fiqh AlAmamiyah", he has proposed a section titled "self-defense" and has elaborated the several issued of defense such as the effect of defense in removing the criminal responsibility of the defendant, the proportion of defense with aggression, self-defense range and etc. self-defense is realized when we are sure about the intention of the aggressor on the offense or aggression. Also, the defender is not allowed at all to act for the removal of threat more than the extent of necessity and need and if he does otherwise, will be proportionally responsible and punished.

\section{THE PRINCIPLES OF SELF-DEFENSE}

The law scholars have proposed different ideas on the legitimacy of criminal act while defending. Some of them consider the spiritual obligation as the basis of the legitimacy of defense and believe that when someone is threatened, cannot control his acts due to excitement and distortion of will, and he is obliged to commit a crime. According to this theory, the criminal act's nature is not changed while defending, but it is not attributable to the defender due to denial of his will.

\subsection{Justifiability of Defense based on the Less Harmful Results}

"Less harmful results" is a consequential theory that deems the self-defense justifiable since compared to attack, it has less harmful results. Those who believe in this theory, consider the self-defense as an exception to the use of force as a crime. Using the force is a crime in normal situations and has harmful results, however in selfdefense and at the presence of conditions, the priority is using it. The criterion for priority of using the force while self-defending is the evaluation and comparison of the defender's defense and the offender's act.

In the normal situation, the offender and defender life is equal and has the same value, however in the case of offending and aggression, this balance is distorted and the offender's life is not equally valuable. To the same proportion, protection of the offender's life is more important. In this theory, the offender's offense is a factor affecting the equality of his life value with the defender's life and lead to the legibility of the use of force by the defender.

There are two objections on this theory. Firstly, their ethical value aside, people are equally valued and the ethical values cannot be a criterion for life inequality. Secondly, if the ethical values are deemed as a criterion affecting the life, there are which obstacles not to generally evaluate the ethical value of each parties of the aggression? For example, if the defender is a dangerous 
natural born killer and the attacker is an exceptional doctor, according to this benefit-based criterion, the ethical value of the doctor must be deemed higher than a natural born killer? (WALERESTIEN, 2005).

\subsection{Justifiability of the Defense based on the Ability to Blame the Offender}

In this theory, what is the basis for the legitimate defense is not the defender's right to defend his life or property or removal of the offender's right to live, but it is the eligibility of the offender's act, the possibility to blame him, and his ethical responsibility in creation of the offense. According to this principle, not any aggression is defensible, and the defender will have the right of defending against the offenses that can be blamed.(McMahan , 2005 : 10) Therefore, the defense against the legible attacker, the offender without the criminal responsibility, and the passive threat, is not allowed (WALLERESTIEN, 2011; FERZAN, 2005).

Those who believe in this cause do not consider the self-defense mischievous, or even less mischievous, but they consider it as the best action expected. In this theory, self-defense is not merely an act legible by the legislator, but it is ethically justifiable and legible. Regarding these introductions, the ethicality and legibility condition of the defender's act is that the offender can be blamed.

The arguments of those who believe in this theory are as follows:

a) Everybody has the right to live unless he committed a crime that eliminates this right.

b) Removal of the right to live is either due to the consent to murder or blamable threat and attack

c) The innocent offender and passive threatening while offending have no ethical responsibility and cannot be blamed.

d) Regarding the lack of ethical responsibility of the offender, he keeps the right to live.

e) If someone keeps his right to live, killing him is eligible.

f) Therefore, killing the innocent offender and passive threatening person is eligible (QOUNG, 2007).

Although Killing innocent offender and passive threatening person according to this theory, is not legible based on the selfdefense, but those who believe in this idea deem legible a defense like the necessity for removal of threat, against these people and claim that this has wrongly extended the range of the self-defense against the passive threat and innocent offender. The restriction of the England Law on the defense is the necessity that makes the lawyers who abide by this rule, extend the range of self-defense against the passive threat and innocent offender (SANGRO, 2006).

This theory extends the range of the defense against the attempted attack or the initials of the attack to the same extent it confines the self-defense range. The explanation is that if the offender has subjectively the intention of attack, but the conditions of the attack are not objectively prepared, the right for the defender to defend is preserved to the maliciousness of the attacker and the fact that he can be blamed. For example, the attacker with the intention of killing someone else, intends to shoot the defender. The defender, with consideration of the possible danger, defends and kills the attacker. The defender attack in this exam- 
ple due to the fact that the attacker's act can be blamed, is a case of self-defense even if, later on it is proven that the attacker gun was empty (QOUNG, 2007). The criticism of the first part of this theory is that it mixes the self-defense with the punishment. The authentication of the ability to blame the perpetrator is only necessary while executing the punishment and not as the self-defense. The critiques believe that self-defense is a legal solution according to which the defender intends to protect and preserve his life and not as a punishment of the offender. Therefore, the authentication of the punishment conditions in selfdefense is illogical and useless (WALLERESTIEN, 2005).

\subsection{Justifiability of the defense due to the offense and aggression to the defender's right to live}

Aniak, Thomason, and Liveric, among the believers of this theory, assert that everybody has the right to live. This right is eliminated when someone offends someone else's right to live. In this situation, the one whose right to live is endangered, has the right to kill the offender (KINLER, 1998).

The basic difference between this theory and the previous theory is that here, the right to defend is not dependent on the fault or the ability to blame the offender, but the very attack and threat to the defender will lead to the right to defend, be the attacker guilty or innocent, or the threat is passive or active. Regarding such argument, Thomason consider the right to defend for the defender in all the three following examples:

1- Attacks with the intention to kill someone else.
2- The offender, without having knowledge of the attack or its nature, endangers someone's life such as the insane or minors.

3- An overweighed person is pushed towards someone. In this example, if the endangered person does not defend himself, will be crushed under the overweight person's body (THOMASON, 1991).

\subsection{Justifiability of the defense based on the aggressor's responsibility}

This is the McMahan's and its summary is that if someone creates a threat or attack on free will and predictably, even if he cannot be blamed, is responsible and defense against him is legible and justifiable. However, if his act is objectively justifiable and he has no responsibility for his act, defense against him will not be legible even if his act is threatening (TOMASON, 1991; UNIACK, 1994). According to McMahan, the offender who can be blamed and the irresponsible offender such as the insane and minors, have done an act that is not objectively legible, therefore there is no doubt in their responsibility and so, defense against them is legible. Similarly, if the person, intentionally or even unintentionally, performs an act that endangers others, he is responsible for his act and defense against him will be legible (MC MAHAN, 2005). In this regard, the following example is of note. A careful driver who always controls his car and is careful while driving, for some reasons which are not predictable, loses the control of the vehicle and drives towards the pedestrians. According to McMahan, in this example, the intentional option of driving a vehicle which involves the possibility of endangering the other people's life, though 
tiny, suffice for the responsibility of the driver and self-defense against him by the pedestrians (MC MAHAN, 2005).

But according to this theory, if the person has not performed any acts, and his status or position endangers others, he cannot be responsible and consequently, defense against him is not legible. Therefore, the passive threatening person who has not performed any acts and only his status has led to endangering others, cannot be subject to self-defense (MC MAHAN, 2005). In this regard, if the person's act is legible and legitimate, such as a bomber who legitimately and legibly set a bomb, has no responsibility. Consequent to the bomber's irresponsibility, even if his act can endanger other people's lives, will not lead the self-defense right for the innocent. In this regard, this theory is not different with that of defense right based on the ability of blaming the offender and also the defense right based on the illegible offense of others' lives (MC MAHAN, 2005).

There also objections on this theory as followings:

1- Firstly, it concentrates on the act of the offender in order to justify the selfdefense and so, tries to find the cases in which the offender has performed an act that bears him a responsibility while it is correct to focus on the self-defense right of the defender paying attention to the defender and his life (QOUNG, 2007). The critiques believe that instead of looking for a blamable threat in the self-defense, we should look for an unjustifiable threat (WALERESTIEN, 2009). Therefore, in any case in which there is unjustifiable attack and threat to someone's life or property, defending against this threat will be allowed and legible, even though this threat cannot be blamed or have responsibility.

2- Secondly, if the responsibility of the offender or threatening person, according to McMahan, is the condition for selfdefense against him, in the driver example, civil enforcement, and in the former, the criminal sanction is not applicable. How we can consider self-defense against him? (FERZAN, 2009). In other words, if the responsibility criterion is the condition for the self-defense, according to the opposition to the driver example, no ethical responsibilities can be attributed to him (KAUFMAN, 2009).

3- The critiques believe that if defending against the careful driver is legible, the defending against the bomber should also be legible, since his act and its danger for the innocents is fairly more predictable than the act of the driver. On the other hand, in the legible bomber example, what harms has the innocent people done that must surrender to death without and rights to defense?

\subsection{Justifiability of defense based on the defender right for denial and removal of offense}

Those who believe in this idea have separated the self-defense from the punishment and argue that contrary to the punishment that is a posteriori subject and requires the criminal performance evaluation and authentication of the possibility of blaming him, the self-defense is a priori subject which seeks to remove the offense to the life (FLETCHER, 1980, 2004). In this theory, instead of relying on ethical evaluation of the offender and his fault, the focus is on the act that is performed in the form of attack or threat (QOUNG, 2007). In this theo- 
ry, the offender is someone who should pay for all of his attacks and threats, even if these attacks or threats are caused by bad luck. On the other hand, the defender is someone who has the right to remove any kinds of attack or threat to him (WALLERESTIEN, 2009).

The person A, without having knowledge and being informed, has taken drugs and due to lack of controlling his acts, couldn't control his vehicle and his car is about to crash into the mountain. The only way he can survive is to crash into the person $B$. in this example, the right to defend against the person $A$ is preserved for person $B$. the person $A$ is an unlucky attacker and threat who should pay for his act. Amongst these consequences is the defender's right to defend (WALLERESTIEN, 2009).

This theory is defendable and logical to the extent it considers the defender's right for the removal and denial of the attack to him, as the basis of self-defense. However, in the section that considers the act of the offender who cannot be blamed (the offender without the criminal responsibility such as the insane or the minors) as the attack that does not deny the offender's right to live, it can be criticized. The basic objection on this theory is that by predicting the defense right for the offender who cannot be blamed (minor or insane), the border between the legibility conditions and the denial causes is ignored.

Concluding the proposed ideas, the latter idea which considers the defender right for removal and denial of the offense as the basis for self-defense, seems more logical. In the self-defense, the defender faces a threat or offense against which he has no way but to defend. If we consider the removal of threat from the defender as the basis for self-defense, there will be no defense against the offender who can be blamed, the offender without criminal responsibility, the passive threat, and even the legible threat. However, the difference between the attack and threat status is that in the passive threat and also legible threat, the act of threatening person is not necessarily crime; therefore, these persons are not denied of their counter-defense and resistance.

\section{CONCLUSION}

Self-defense is one of the legal entities included in the legal texts over time, in order to defend the rights of communities and different legal systems and its subject is mainly defending one's or someone else's life, land, honor, property, and personal freedom. This legal entity is as old as human life, i.e. it is granted to the man from his birthday as a defensive entity against any aggression or danger and it is amongst anybody's natural rights. Under the codified law of the countries, people who comply with the conditions mentioned in legal articles to defend their actions, their acts will be legible and they will bear no criminal and civil responsibility.

For justification of the self-defense against the attack to the life or threatening it, there have been proposed several theories. Some scholars believe the possibility of blaming the offender to be the basis of selfdefense. Some consider the less harms to the offender, and some consider the selfdefense justifiable since other people's lives is endangered. According to another idea, the possibility of blaming or not blaming the offender aside and without the consideration of justifiability of the offender's act, the 
innocent defender who is endangered or threatened, has the right to defend himself. The latter idea which seems acceptable, by focusing on the defender instead of the offender, consider the defender's right of living as the basis for the self-defense right against attack to the life or threatening it. Therefore, the defender who is exposed to attack and threat, be the offender blamable or not, or his offense is legible or not, has the right to defend himself.

\section{REFERENCES}

ARDABILI, M. A. Basic Criminal Law, Volume I, Tehran, the legal foundation, 2011.

BAHERI, M. General view of the criminal law, Third Edition, Tehran, Majd Publications, 2004.

BARKIER, D. \& P. C. Law Made Simple, Fourth Edition, Majd Publications, 2011.

BORJI, Y. the necessity of self-defense from the perspective of both sects, High School Imam Khomeini, Number 15, 2015.

FERZAN, K. K. Justifying Self-defense, Low and philosophy, SAMT Publication, 2005.

FIETCHER, G. P. American Low in a Global Context the Basics, New York, Oxford University Press, 2005.

JAFARI LANGROODI, M. J. Terminology of law, the twenty-fifth edition, Tehran, treasure of knowledge, 2005.

KINLER, P. S. self - defense and Killing, Thesis submitted to the faculty of the Virginia poly technical Institute and Statue University, 1998.

MC MAHAN, J. Self - defense and Culpability, Low and philosophy, Uni Publication, 2005.

MIR MOHAMMAD, S. H. Criminal Law of crimes against persons, Tenth Edition, Tehran, Mizan Publishers, 2012.
QOUNG, J. Killing in Self - defense, politics, University of Manchester, 2007.

ROUSSEAU, J. J. The Social Contract, translated by Morteza Kalantarian, Mizan Publishers, 2013.

SANGRO, B. Self - Defense in Criminal Low North, Fontana Press, American Hart Publishing, 2006.

SHAMBAYATI, H. Basic Criminal Law, Volume First, Second Edition, Tehran, Mizan Publishers, 2008.

THOMASON, J. J. Self - defense, philosophy and public Affairs and Unpack, Suzanne, Permissible Killing, Cambridge University Press, 1991.

WALERESTIEN, S. justifying The Right to Self- defense, Virginia Low Review, 2005.

WALERESTIEN, S. Why Causal Responsibility Matters, Jeff Mc Mahan, Self - defense against Morality Innocence and Replay to Commentators, Criminal Low Conservation, New York oxford, university, 2009.

WALIDI, M. S. Basic Criminal Law, Volume II, Third Edition, Uraman Publication, 1995.

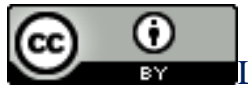
License information: This is an openaccess article distributed under the terms of the Creative Commons Attribution License, which permits unrestricted use, distribution, and reproduction in any medium, provided the original work is properly cited.

Article received on October 20, 2017.

Evaluated November 22, 2017.

Accepted on November 23, 2017.

Published on December 19, 2017.

How cite this article (ABNT):

KHOZOUIE, Parviz; AFANDAK, Khalil; MEHRVAND, Mina. A Study on the Current Theories of the Philosophy and Principles of Self-Defense. Estação Científica (UNIFAP), Macapá, v. 7, n. 3, p. 19-28, set./dez. 2017. 